\section{'Ivana' Peach}

\section{Vladislav M. Ognjanov', Maja Miodragović, Goran Barać, Mirjana Ljubojević, Jovana Dulić, Mirjana Sekulić, and Tijana Narandžić}

Department of Fruit Growing, Viticulture, Horticulture and Landscape Architecture, Faculty of Agriculture, University of Novi Sad, Novi Sad 21000, Serbia

Additional index words. Prunus persica, cultivar, fruit breeding, mutation
'Ivana' is a yellow peach cultivar released in 2016 by the University of Novi Sad, Faculty of Agriculture, Autonomous Province of Vojvodina, Serbia. It is an excellent early ripening commercial cultivar for fresh consumption selected as spontaneous mutant of tions of northern Serbia, it has a middle blossoming period, beginning of flowering is generally $2 \mathrm{~d}$ after 'Spring lady'. Its fruits mature at the end of June, $2 \mathrm{~d}$ before 'Spring lady'. 'Ivana' is a medium vigor cultivar with open spreading tree habit, precocious, high cropping, consistently productive with outstanding fruit quality. Its medium to large dark purple red, low pubescence and firm fruit makes it different to its original cultivar Springcrest.

\section{Origin}

Ivana has been selected as spontaneous mutant of 'Springcrest' peach cultivar in the village Udovice, Belgrade district, Republic of Serbia, as a part of the Stone Fruit Breeding Program at the University of Novi Sad, Faculty of Agriculture, Department of Fruit growing and viticulture, Novi Sad. The cultivar was selected in 2006 by Dr. Vladislav Ognjanov, University of Novi Sad, Faculty of Agriculture, and Nikolić Radosav, local selection activist from the village Udovice.

The mutation was propagated in more than 500 trees on "vineyard peach seedling" and 'GF 677' rootstocks using summer grafting. For testing, 1-year-old nursery trees produced in 2008 were planted in a highdensity orchard. Three-year and older trees of the mutation and control cultivars were subsequently evaluated in 2010-12 at two high chill locations.

The official trials for cultivar release, funded and initiated by the Ministry of Agriculture of Serbia, were planted at two locations-Novi Sad and Cačak in 2012. At least 15 trees, divided in three replications, were used as test plots. The experimental design was completely randomized, with 'Springcrest' and 'Spring lady' as standard cultivars. 'Springcrest' was chosen as the

Received for publication 23 Mar. 2018. Accepted for publication 27 Apr. 2018.

${ }^{1}$ Corresponding author. E-mail: vognjanov@polj. uns.ac.rs. 'Springcrest' cultivar. In the climatic condi- control cultivar where mutation occurred and 'Spring lady' served as an advanced, early ripening, well-adapted standard cultivar (Aliman et al., 2014). Officially, elected Ministry Committee of experienced horticulturists and growers assessed the developmental and fruiting characteristics of the potential new cultivar three times a year. Distinctness, uniformity, and stability (DUS) and value for cultivation and use tests were conducted based on characterization and evaluation of data during the three consecutive fruiting years, from 2014 to 2016, using the UPOV (2010) peach (Prunus persica) descriptor for DUS. Characterization and evaluation presented in this article were carried out using the samples that were part of the experimental trial conducted in Novi Sad, Experimental station Rimski Šančevi (lat. $45^{\circ} 34^{\prime}$ N, long. $19^{\circ} 84^{\prime} \mathrm{E}$; altitude $95 \mathrm{~m}$ a.s.1.) according to the descriptor list for peach (Bellini et al., 1984).

Molecular profiling of cultivars Ivana and Springcrest, using simple sequence repeat markers, demonstrated uniformity proving that 'Ivana' is a mutation of 'Springcrest'. The fruits in Picture 1 were taken from the tree where mutation occurred, representing clear difference in pomological characters. Mutation was stable in the first and second generation of grafted trees, in aggregate more than 500 fruiting trees, without any reversion phenomenon.

The aim of the research was to provide information on the new peach cultivar Ivana and to conduct its evaluation in comparison with standard cultivars with respect to tree habit, productivity, fruit quality attributes, and disease tolerance.

\section{Description}

Tree and leaf. 'Ivana' is being released for use in the medium to high chill zones (700 900 chill unit accumulation). Accumulated chill units were $825.2 \pm 36.9$ calculated by the 'Utah' model for peach (Richardson and Seeley, 1974) from 2014 to 2016. The tree is medium vigorous (intermediate) with the typical spreading natural architecture of the canopy. One-year-old shoots are the most important fruiting wood, thick with normal internode length. Two lateral flower buds and one vegetative bud in the middle are evenly distributed along the shoots axis. The foliage is dense and evenly distributed across the long, 2-3 cm broad, and pinnately veined. They have two reniform nectaries and crenate margins.

Inflorescence. 'Ivana' has an intermediate season of flowering, few days after 'Spring lady', and strong blossom quantity. Hermaphroditic flowers have five showy pink petals, yellow anthers with abundant pollen, and are self-fertile. Double flowers occur very rarely.

Fruits. The fruit characteristics presented in this article are the mean values for three experimental years. 'Ivana' is a very early ripening cultivar, the onset of fruit ripening starts $1 \mathrm{~d}$ earlier than in 'Springcrest' and $2 \mathrm{~d}$ earlier than in 'Spring lady' (Table 1). Its fruit is medium-sized $(152.4 \mathrm{~g})$, round in shape, with perfectly symmetric halves. The fruit skin adheres to the mesocarp and is dark entire tree. The leaves are lanceolate, $7-16 \mathrm{~cm}$

Table 1. Average fruiting characteristics and disease susceptibility of 'Ivana' peach cultivar compared with leading standard cultivars of same ripening seasons 'Springcrest' and 'Spring lady' during the three consecutive fruiting years, from 2014 to 2016.

\begin{tabular}{llll}
\hline & \multicolumn{1}{c}{ Springcrest } & \multicolumn{1}{c}{ Ivana } & \multicolumn{1}{c}{ Spring lady } \\
\hline Harvest maturity & 2 (27 June) & 2 (26 June) & 2 (28 June) \\
Season of flowering & 5-Intermediate & 5-Intermediate & 4-Early/intermediate \\
Flower type & 1-Rosaceous & 1-Rosaceous & 2-Campanulate \\
Cropping efficiency & 7-Very high & 7-Very high & 7-Very high \\
Fruit weight (g) & 143.4 b & 152.4 a & 147.5 ab \\
Fruit shape & 3-Rounded & 3-Rounded & 3-Rounded \\
Ground color & 6-Orange yellow & 6-Orange yellow & 6-Orange yellow \\
Blush type & 5-Partly red & 9-Red wine & 9-Red wine \\
Blush \% & 40 b & 85 a & 80 a \\
Skin pubescent & 7-High & 3-Poor & 5-Intermediate \\
Firmness of flesh & 7-Firm & 9-Extremely firm & 9-Extremely firm \\
Stone adherence to flesh & 3-Clingstone & 2-Semi freestone & 2-Semi freestone \\
Split stone & 5-Medium & 2-Very low & 3-Low \\
Tree habit & 5-Spreading & 5-Spreading & 5-Spreading \\
Tree vigor & 7-Strong & 5-Intermediate & 5-Intermediate \\
Disease susceptibility & & & \\
\multicolumn{1}{l}{ Monilinia fructicola } & 5-Medium & 5-Medium & 5-Medium \\
Sphaerotheca pannosa & 5-Medium & 5-Medium & 5-Medium \\
Taphrina deformans & 7-High & 7-High & 7-High \\
Xanthomonas spp. & 3-Low & 3-Low & 3-Low \\
\hline
\end{tabular}

Means within a row followed by the same letter are not significantly different at $P \leq 0.05$, as established by Duncan's multiple range tests. 


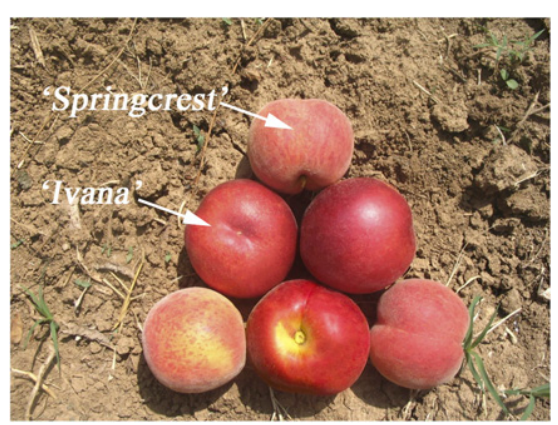

Fig. 1. 'Ivana' and 'Springcrest' fruits picked onsite from the tree where bud mutation occurred.

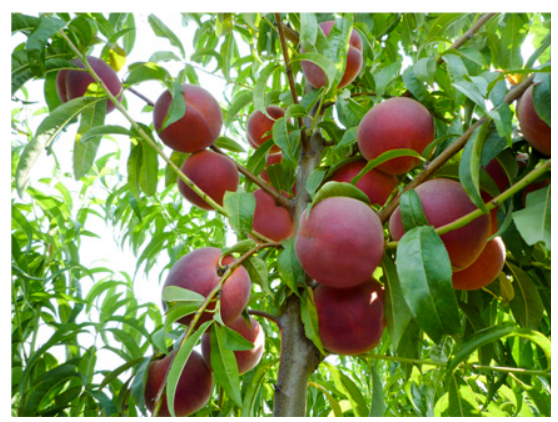

Fig. 2. Extensively red blushed, extremely low pubescence fruits of 'Ivana' peach on the tree.

purple-red in color at maturity. The skin is much less pubescent than in 'Spring lady' and 'Springcrest', making the fruit attractively brightly colored (Figs. 1 and 2). In addition, along the suture 'Ivana' does not form the russeted line like 'Spring lady' does. The flesh is yellow, firm, juicy, and sweetacidic in taste. The cultivar has a remarkable keeping quality, particularly on the tree, and a long shelf life, which is a rewarding characteristic for both growers and consumers (Layne and Bassi, 2008).

\section{Performance and Uses}

'Ivana' has good compatibility with "vineyard peach seedling" and 'GF 677' rootstocks. Regardless of the type of graft, successful take of the dormant bud has been recorded using summer grafting (July and August). The tree size and vigor are medium with spreading growth habit that enables dense planting for commercial fruit production, $4 \times 2 \mathrm{~m}$. Fusetto or free spindle training system can be successfully applied without suffering from excessive shading and loss of bearing wood in the inner and lower parts of the canopy. Dormant pruning, summer pruning and summer topping are the important tools for precocious flower bud formation and great number of flowers developed along the entire shoot length. Good pollen germination and flower fertility resulted in a high fruit set

Table 2. Average quality parameters of fruits harvested from 'Ivana' and standard cultivars Springcrest and Spring lady during the three consecutive fruiting years, from 2014 to 2016.

\begin{tabular}{lcccccc}
\hline & \multicolumn{7}{c}{ Quality parameters } \\
\cline { 2 - 7 } & $\begin{array}{c}\text { Soluble } \\
\text { Solids (Brix) }\end{array}$ & $\begin{array}{c}\text { Invert } \\
\text { sugars (\%) }\end{array}$ & $\begin{array}{c}\text { Total } \\
\text { sugars }(\%)\end{array}$ & $\begin{array}{c}\text { Sucrose } \\
(\%)\end{array}$ & $\mathrm{pH}$ & $\begin{array}{c}\text { Titratable } \\
\text { acidity }(\mathrm{g} / 100 \mathrm{~mL})\end{array}$ \\
Springcrest & $9.43 \mathrm{~b}$ & $2.4 \mathrm{a}$ & $7.7 \mathrm{a}$ & $5.0 \mathrm{~b}$ & $3.48 \mathrm{a}$ & $0.70 \mathrm{a}$ \\
Ivana & $11.97 \mathrm{a}$ & $2.7 \mathrm{a}$ & $8.4 \mathrm{a}$ & $5.4 \mathrm{a}$ & $3.53 \mathrm{a}$ & $0.68 \mathrm{a}$ \\
Spring lady & $11.67 \mathrm{a}$ & $2.6 \mathrm{a}$ & $8.2 \mathrm{a}$ & $5.3 \mathrm{a}$ & $3.48 \mathrm{a}$ & $0.72 \mathrm{a}$ \\
\hline
\end{tabular}

Means within a row followed by the same letter are not significantly different at $P \leq 0.05$, as established by Duncan's multiple range test.

requiring hand thinning (Corelli-Grappadelli and Coston, 1991). Double fruits coming from the same spot are rare even in the years with drought stress at the time of flower formation. Fruit quality was slightly dependent on its position within the canopy because light interception does not significantly influence the fruit coloring (Fig. 2). 'Ivana' has low incidence of fruit cracking and little preharvest drop. Yield was not different from 'Spring lady' and 'Springcrest' with slightly greater average fruit weight (Table 1).

The average soluble solids content of 'Ivana' was 11.97 brix when fully ripe. Titratable acidity was $0.68 \%$ (malic acid aquivalent) which is lower than in 'Springcrest' and 'Spring lady' (Table 2). Titratable acidity was obtained using a digital bottle-top burette $\left(\right.$ BRAND ${ }^{\circledR}$ Titrette $^{\circledR}$, Darmstadt, Germany). The total sugars and invert sugars content were determined by the Luff-Schoorl method as described by Egan et al. (1981). The sucrose content was calculated according to the relationship: $\mathrm{SU}=(\mathrm{TS}-\mathrm{RS}) \times 0.95$ ( $\mathrm{SU}=$ sucrose content; $\mathrm{TS}=$ total sugars $(\%)$; $\mathrm{RS}=$ reducing sugars). The results were expressed in \% of fresh weight.

'Ivana' is an excelent example of on-farm conservation of fruit genetic resources and selection of naturally occurring bud mutations in colaboration with farmers. The fruit breeding group from the Faculty of Agriculture, Novi Sad, for decades educated fruit growers with the aim to increase their awareness on spontaneous mutations occuring in nature at random.

In conclusion, 'Ivana' differs to 'Spring lady' and 'Springcrest' in fruit attractiveness being a typical modern peach with yellow skin, extensive red blush, extremely low pubescence, good firmness, and excellent eating quality. Early harvest timing, combined with its outstanding fruit attractiveness place 'Ivana' peach cultivar in a unique position on the marketplace, equally domestic and when exported (Crisosto et al., 2006; Ognjanov et al., 2017).

\section{Disease and Pest Reaction}

All examined cultivars were evaluated for susceptibility to fungal and bacterial diseases in naturally infected plots and scored according to the descriptor list for peach (Bellini et al., 1984). The findings revealed that 'Ivana' has equal susceptibility as control cultivars to brown rot (Monilinia fructicola), powdery mildew (Sphaerotheca pannosa), leaf curl (Taphrina deformans), and bacterial leaf spot caused by the bacteria Xanthomonas campestris pv. Pruni.

\section{Availability}

Limited quantities of budwood are available for testing and commercial propagation from the Faculty of Agriculture, Department of fruit growing, viticulture, horticulture, and landscape architecture, Novi Sad, Serbia. Ivana is not a patented cultivar. Budwood source trees are virus-tested negative.

\section{Literature Cited}

Aliman, J., A. Džubur, S. Hadžiablić, A. Skender, D. Bećirspahić, and F. Behmen. 2014. Quantitative characteristics of introduced peach cultivars in Hercegovina. The 5th International Symposium on Sustainable Development [ISSD 2014] "Biotechnology for Sustainable Development" May 15-18, Sarajevo. p. 63-68.

Bellini, E., R. Watkins, and E. Pomarici. 1984. Descriptor list for peach (Prunus persica). IBPGR secretariat, Rome, Italy.

Corelli-Grappadelli, L. and C.D. Coston. 1991. Thinning pattern and light environment in peach tree canopies influences fruit quality. HortScience 26:1464-1466.

Crisosto, C.H., G.M. Crisosto, and F. Neri. 2006. Understanding tree fruit quality based on consumer acceptance. Acta Hort. 712:183-189.

Egan, H., R. Kirk, and R. Sawyer. 1981. Pearson's chemical analysis of foods. 8th ed. Longman, Harlow, UK.

Layne, R.D. and D. Bassi. 2008. The peach botany, production and uses. CAB International, London, UK.

Ognjanov, V., G. Zec, M. Ljubojević, G. Barać, J. Dulić, and M. Miodragović. 2017. Savremena proizvodnja breskve. Savetovanje "Savremena proizvodnja voća”, Banja Koviljača, Zbornik apstrakata. p. 19-22.

Richardson, E.A. and D.S. Seeley. 1974. A model for estimating the completion of rest for 'Redhaven' and 'Elberta'peach trees. HortScience 9:331-332.

UPOV. 2010. Guidelines for the conduct of tests for distinctness, uniformity and stability. Peach. TG/53/7. International Union for the Protection of New Cultivars of Plants, Geneva, Switzerland. 